\section{Physiological Effects of Trihydroxy-N- Methylindol and its Reaction with Copper Ions}

TRIHYDROXY-N-METHYLINDOL, a highly fluorescent substance derived from adrenochrome ${ }^{1-4}$, sensitizes the smooth muscles of the cat to the excitatory (nictitating membrane) and inhibitory (non-pregnant uterus) actions of adrenaline ${ }^{5}$.

This substance has a great affinity for copper ions. The fluorescence of $\mathrm{a} 2 \times 10^{-6}$ solution disappears in three minutes at laboratory temperature in the presence of $1 \times 10^{-6}$ copper ions (as copper sulphate) ; it inhibits the oxidation by copper ions of adrenaline in aqueous solution. A substance has been isolated and analysed which corresponds to the formula $\mathrm{C}_{9} \mathrm{H}_{7} \mathrm{NO}_{3} \mathrm{Cu}+\mathrm{H}_{2} \mathrm{O}$ or $\mathrm{C}_{18} \mathrm{H}_{14} \mathrm{~N}_{2} \mathrm{O}_{6} \mathrm{Cu}_{2}+2 \mathrm{H}_{2} \mathrm{O}$ (found: $\mathrm{C}, 42 ; \mathrm{H}, 3.6 ; \mathrm{N}, 5 \cdot 1 ; \mathrm{C}_{18} \mathrm{H}_{14} \mathrm{~N}_{2} \mathrm{O}_{6} \mathrm{Cu}_{2}$ requires $\mathrm{C}, 41.5 ; \mathrm{H}, 3.5 ; \mathrm{N}, 5.4$ per cent).

The hypothesis may be put forward that the physiological actions of trihydroxy-N-methylindol (decrease of bleeding time $\theta^{6}$ and of capillary permeability, sensitization to adrenaline) are related to its copperbinding activity in accordance with the general concept formulated by Lavollay", Javillier and Lavollay ${ }^{8}$, Clark and Geissman', in order to explain the 'vitamin P'-like actions of flavonoids and related substances.

$$
\begin{aligned}
& \text { P. Fischer } \\
& \text { J. Lecomte } \\
& \text { L. DelandtSheere }
\end{aligned}
$$

Laboratory of General Pathology,

Laboratory of Medical Pathology,

University of Liège. Aug. 3 .

' Harley-Mason, J., J. Chem. Soc., 1276 (May 1950).

2 Lund, A., Acta Pharm. Toxic., 5, 121 (1949).

"Fischer, P., Bull. Soc. Chim. Belgique, 58, 206 (1949).

- Fischer, P., Derouaux, G., Lambot, H., and Lecomte, J., Bull. Soc. Chim. Belgique, 59, 72 (1950).

- Fischer, P., and Lecomte, J., Arch. Int. Physiol., 58, 236 (1950).

- Fischer, P., and Trabert, P., Experientia, 6, 392 (1950).

'Lavollay, J., "L'autooxydation des Diphénols" (Paris : Hermann, 1943).

- Javillier, M., and Lavollay, J., Helv. Chim. Acta, 29, 1283 (1946).

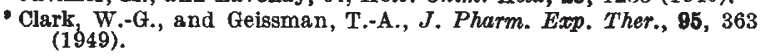

\section{'Y-Protein': a New Component of the Muscle Machine}

We have recently shown ${ }^{1}$ that if rabbit muscle is extracted with a solution of high ionic strength (potassium chloride $>0 \cdot 5$ ), the electrophoretic test (Tiselius-Longsworth, see ref. 2) shows, besides the proteins already described ${ }^{3-7}$, a new component that we have called ' $Y$-protein'. At ionic strength 0.40 and $p \mathrm{H} 7 \cdot 4$, it moves more slowly than $\beta$-myosin.

This new protein exists only in extracts of normal resting muscle. If the muscle has been previously subjected to contracture by pharmacological means (monoiodoacetate) or rigor mortis, neither $Y$-protein nor $\beta$-myosin can be found in the extracts if potassium chloride is used for the extraction ${ }^{6}$. This is due to the presence of strong linkages between those proteins and muscle stroma, in the contracted state. These linkages cannot be broken by potassium chloride, but are broken by potassium iodide or pyrophosphate solutions ${ }^{1}$.

We have succeeded in isolating $Y$-protein. Normal resting muscle is progressively frozen in a $-20^{\circ} \mathrm{C}$. chamber, cut in $50-\mu$ slides by use of a freezing. microtome ${ }^{8}$, extracted for ten minutes with 5 vol. Weber-Edsall solution $(0.6 \mathrm{M}$ potassium chloride, $0.04 M$ sodium bicarbonate, $0.01 M$ sodium car- bonate; the addition of 0.3 per cent adenosinetriphosphate does not affect the amount of $Y$-protein extracted). Extraction and the following operations are carried out in a cold room at $\pm 1^{\circ} \mathrm{C}$. After centrifugation, the liquid is progressively mixed with saturated ammonium sulphate solution at $p \mathbf{H} \mathbf{6 \cdot 0 0}$ (53 c.c. sulphate solution for 100 c.c. extract, which corresponds to 35 per cent saturation).

The electrophoretic analysis of the precipitate shows that it contains $\alpha$-myosin (actomyosin), $Y$. protein and some myogenes. $\beta$-myosin remains in the solution (it is precipitated only at 37-40 per cent saturation in ammonium sulphate at $p \mathrm{H} 6 \cdot 00^{9}$ ). The precipitate containing $Y$-protein is washed with ammonium sulphate solution at 35 per cent saturation and dissolved in $0 \cdot 1 M$ potassium chloride at $p \mathrm{H} 7 \cdot 6$. The solution, which is rather turbid owing to the presence of actomyosin, is dialysed against a solution of $\mu 0.05(0.016$ disodium hydrogen phosphate, 0.002 sodium dihydrogen phosphate). The actomyosin is precipitated and $Y$-protein remains in the solution.

Electrophoretic controls show that only one component is present. Its velocity is :

at $\mu 0 \cdot 40, p \mathrm{H} 7 \cdot 40:-2 \cdot 7 \times 10^{-5} \mathrm{~cm} . /$ volt $/ \mathrm{sec}$.

at $\mu 0 \cdot 10, p \mathrm{H} 7 \cdot 60:-3 \cdot 4 \times 10^{-5} \mathrm{~cm} . /$ volt $/ \mathrm{sec}$.

In an extract of whole muscle, in which $Y$-protein is present as well as all the other muscle proteins, the velocity of the $Y$-protein is much reduced:

at $\mu 0 \cdot 40$ and $p H 7 \cdot 40: 2 \cdot 65 \pm 0.1 \times 10^{-5} \mathrm{~cm} . /$ volt $/ \mathrm{sec}$.

Solutions of $Y$-protein are rather clear, slightly viscous and do not show double refraction of flow. Optical properties do not depend on ionic strength between 0.005 and 0.5 .

$Y$-protein is insoluble in distilled water, fairly soluble in solutions at $\mu 0.005, p H \mathbf{H}$.4. The fact that the new protein can be extracted only by using solutions of at least a hundred times ionic strength indicates that $Y$-protein is not free in the musele cell, but connected to some part of the insoluble stroma from which it is liberated by solutions of high ionic strength.

This property explains why $Y$-protein has not been isolated before. It cannot be present in low ionic strength extracts such as those prepared for isolation of the proteins of the myogen group or the. $X$-globulins. When extracts of high ionic strength are made, they are usually prepared to extract the myosinswhich are precipitated by dilution-and $Y$-protein is not precipitated in those conditions, being still soluble at $\mu 0.005 M$.

That the binding forces which maintain the $Y$-protein in the muscle cell are considerably increased in the contracted state seems to be a proof that the new protein takes part in the constitution of the muscle machine.

Laboratory of General Biology,

M. Dubuisson Faculty of Sciences,

University of Liège. July 27.

${ }^{1}$ Dubuisson, M., Biochem. et Biophys. Acta, 5, 489 (1950).

Dubuisson, M., Distèche, A., and Debot, A., Biochem. et Biophys. Acta (in the press).

-Dubuisson, M. "Jues protéines musculaires". Exposés Annuels de Biochimie Médicale, 9ème série (Paris, 1948).

- Dubuisson, M., Bull. Acad. Sci. Belg., 33, 769 (1947).

${ }^{5}$ Dubuisson, M., Bull. Acad. Sci. Belg., 34, 978 (1948).

- Dubuisson, M., Biochem. et Biophys. Acta, 4, 25 (1950).

"Dubuisson, M., "Le cycle de la contraction musculaire et la structure physico-chimique de l'édifice contractile", Congrès de l'Assoc. des

Dubuisson, M., Experientia, 3, 372 (1947).

'Dubuisson, M., Experientia, 2, 412 (1946). 